\title{
5-bromo-3-(3-hydroxyprop-1-ynyl)-2H-pyran-2-one induces apoptosis in T24 human bladder cancer cells through mitochondria-dependent signaling pathways
}

\author{
GUO-QIANG YU, ZHONG-LING DOU and ZHAO-HUI JIA \\ Department of Urological Surgery, The First Affiliated Hospital, College of Clinical Medicine,
Henan University of Science and Technology, Luoyang, Henan 471003, P.R. China
}

Received September 13, 2015; Accepted September 9, 2016

DOI: $10.3892 / \mathrm{mmr} .2016 .5991$

\begin{abstract}
The present study was performed to investigate the effect of 5-bromo-3-(3-hydroxyprop-1-ynyl)-2 $\mathrm{H}$-pyran-2-one (BHP) on the induction of apoptosis and cell cycle arrest in T24 human bladder carcinoma cells. An MTT assay was used to investigate the inhibition of cell proliferation. Flow cytometry was used to observe alterations in the cell cycle, generation of reactive oxygen species (ROS), alterations in mitochondrial membrane potential (MMP) and induction of apoptosis in the T24 cells following BHP treatment. Western blot analysis was performed for the determination of expression levels of apoptotic proteins, and 4,6-diamidino-2-phenylindole dihydrochloride staining was used to observe apoptosis and DNA damage. The results demonstrated that treatment of the bladder cancer cells with BHP enhanced the activation of caspases and increased the production of ROS. It also caused damage to DNA, reduced MMP, and increased the secretion of endonuclease $\mathrm{G}$ and apoptosis-inducing factor from the mitochondria. The expression levels of cyclin $\mathrm{E}$ and cell division cycle $25 \mathrm{C}$ were reduced, whereas the expression levels of p21 and phosphorylated p53 were increased in the BHP-treated cells. In addition, treatment with BHP caused cell cycle arrest at the $\mathrm{G} 0 / \mathrm{G} 1$ phase, increased the expression levels of B cell lymphoma-2 (Bcl-2)-associated X protein and poly(ADP-ribose) polymerase, decreased the expression of Bcl-2 and ultimately induced apoptosis of the T24 cells. Thus, BHP inhibited the proliferation of bladder cancer cells by inducing cell apoptosis through the mitochondrial pathway.
\end{abstract}

Correspondence to: Professor Zhong-Ling Dou, Department of Urological Surgery, The First Affiliated Hospital, College of Clinical Medicine, Henan University of Science and Technology, 24 Jinghua Road, Jianxi, Luoyan, Henan 471003, P.R. China E-mail: douzhonglingzl@hotmail.com

Key words: bladder cancer, apoptosis, caspases, mitochondrial, cell cycle

\section{Introduction}

Bladder cancer is a type of urogenital system tumor, which is commonly detected in the USA, of which $70 \%$ cases are superficial tumors and 30\% represent muscle-invasive disease (1). Every year $>386,000$ patients are diagnosed with bladder cancer worldwide, resulting in a mortality rate of $>150,000$ (2). Despite advances in the field of surgery and chemotherapy for the treatment of bladder cancer, the recurrence rate in patients remains high (3). In addition, the development of chemotherapy-induced side effects have also shown a high rate of incidence (4).

Therefore, the identification of novel molecules for the treatment of bladder cancer and to reduce its rate of recurrence is desired. Certain substance have been identified, which exhibit a toxic effect on the growth of cancer cells by damaging DNA and inducing cell cycle arrest (5-7).

Caspase activation is an important process for inducing apoptosis and, based on their effects, they have been divided into two classes. Caspases are regarded to be key in apoptosis. To date, a total of 14 caspases have been identified, termed caspases 1-14. On the basis of their role in apoptosis, caspases are divided into initiator and effector caspases. The initiator caspases (caspase-2, -8, -9 and -10) are involved in the initiation of apoptosis and the activation of other caspases, whereas the effector caspases (caspase-3, -6 and -7) act on substrates to induce alterations in cellular biochemistry and morphology, which are characteristic of apoptosis $(8,9)$. Apoptosis, also termed programmed cell death, is generally induced either through an extrinsic or intrinsic pathway $(10,11)$. In the case of the intrinsic pathway, the factors responsible include damage to DNA, oxidative stress and the action of cytotoxic candidates within the cell (11).

2-pyrones are cyclic, unsaturated compounds with a six-membered ring structure, isolated from bacterial, plant and animal sources $(12,13)$. 2-pyrones have shown a wide range of biological activities, including chemoprotective (14), antifungal, cytotoxic, neurotoxic and phytotoxic properties (15). In addition, 2-pyrones have been reported to exhibit anticancer and anti-human immunodeficiency virus (HIV) activities (16-18). The treatment of human leukemic cells with tricyclic 2-pyrones causes inhibition of DNA synthesis and cell proliferation (19). 
The present study was designed to investigate the effect of 5-bromo-3-(3-hydroxyprop-1-ynyl)-2H-pyran-2-one (BHP) on alterations in cell cycle and the induction of apoptosis in T24 bladder cancer cells. The results demonstrated that BHP treatment caused cell cycle arrest and induced apoptosis in T24 cells through mitochondrial and c-Jun N-terminal kinase (JNK) signaling pathways.

\section{Materials and methods}

Chemicals and reagents. BHP, MTT and dimethyl sulfoxide (DMSO) were purchased from Sigma-Aldrich (Merck Millipore, Darmstadt, Germany). Propidium iodide (PI), Triton X-100 and trypan blue Dulbecco's modified Eagle's medium (DMEM) were obtained from Santa Cruz Biotechnology, Inc. (Santa Cruz, CA, USA).

Cell culture. The human bladder carcinoma T24 cell line was purchased from American Type Culture Collection (Manassas, VA, USA). The cells were cultured in DMEM (Gibco; Thermo Fisher Scientific, Inc., Waltham, MA, USA) supplemented with $10 \%$ fetal bovine serum (Gibco; Thermo Fisher Scientific, Inc.) at $37^{\circ} \mathrm{C}$ with $5 \% \mathrm{CO}_{2}$.

Cell viability assays. The effect of BHP on the viability of the T24 cells was determined using an MTT uptake method. The cells, at a density of $2.5 \times 10^{5}$ cells per $\mathrm{ml}$ per well, were distributed into 96 -well plates and incubated with various concentrations of $\operatorname{BHP}(0,2,5,8$ and $10 \mu \mathrm{M})$ for $48 \mathrm{~h}$ at $37^{\circ} \mathrm{C}$. Into each well, $10 \mu \mathrm{l}$ of MTT solution was then added, followed by incubation for $2 \mathrm{~h}$ at $37^{\circ} \mathrm{C}$. DMSO was added to each of the wells following replacement of the medium for dissolving the formazan crystals. An enzyme-linked immunosorbent assay was used to measure the absorbance values of each well at $565 \mathrm{~nm}$.

Determination of alterations in cell morphology. The cells, at a density of $2.5 \times 10^{5}$ cells per ml per well, were distributed into 96-well plates and incubated with various concentrations of $\operatorname{BHP}(0,2,5,8$ and $10 \mu \mathrm{M})$ for $48 \mathrm{~h}$ at $37^{\circ} \mathrm{C}$. Inverted fluorescence microscopy (Leica DMI4000B; Leica, Mannheim, Germany) was used to examine the alterations in cell morphology.

Cell cycle analysis. Following incubation with the various concentrations of BHP, the T24 cells were collected, isolated and then fixed using $70 \%$ ethyl alcohol overnight at $-20^{\circ} \mathrm{C}$. The cells were then suspended in phosphate-buffered saline (PBS) supplemented with PI, RNase and Triton X-100 (0.1\%) in the dark at $37^{\circ} \mathrm{C}$ for $45 \mathrm{~min}$. For the analysis of cell cycle distribution, flow cytometeric analysis was performed (Beckman Coulter, Inc., Brea, CA, USA) using an argon ion laser at $455 \mathrm{~nm}$.

Staining with 4,6-diamidino-2-phenylindole dihydrochloride (DAPI). The T24 cells, at a density of $2.5 \times 10^{5}$ cells per ml per well, were incubated with $0,2,5,8$ or $10 \mu \mathrm{M}$ BHP for $48 \mathrm{~h}$, which was followed by DAPI staining. A flow cytometer (Beckman Coulter, Inc.) was used to analyze and capture images of the cells.
Determination of the generation of reactive oxygen species (ROS) and $\mathrm{Ca}^{2+}$. The T24 cells $\left(2.5 \times 10^{6}\right.$ per ml) were treated with $0,2,5,8$ or $10 \mu \mathrm{M}$ BHP for $48 \mathrm{~h}$, harvested and placed in 2,7-dichlorodihydrofluorescein diacetate (DCFH-DA) in order to determine the generation of ROS. In order to determine the production of $\mathrm{Ca}^{2+}, 1$-[2-amino-5-(6-carboxyindol-2-yl) phenoxy]-2-(2'-amino-5' methylphenoxy) ethane- $N, N, N^{\prime}$, $N^{\prime}$-tetra acetic acid pentaacetoxymethyl ester (Thermo Fisher Scientific, Inc.) was used instead of the DCFH-DA. Following incubation for $45 \mathrm{~min}$ at $37^{\circ} \mathrm{C}$, the cells were analyzed using a flow cytometer (Beckman Coulter, Inc.).

Measurement of the mitochondrial membrane potential $(M M P)$. In the present study, Rh123, a cationic fluorescent dye, was used to analyze alterations in the MMP of the cells. For this purpose, Rh123 (Molecular Probes; Thermo Fisher Scientific, Inc.) was added to the cell cultures at a concentration of $2 \mu \mathrm{M}$ at $37^{\circ} \mathrm{C}$ for $45 \mathrm{~min}$. Following incubation, the cells were washed with PBS and confocal laser scanning microscopy (LSM 710; Zeiss, Oberkochen, Germany) was used to capture images of the cells. ImageJ 1.41o software (National Institutes of Health, Bethesda, MA, USA) was used to measure the intensity of the mean fluorescence.

Western blot analysis. Following treatment with BHP, the T24 cells were washed with PBS and lysed in ice-cold lysis buffer containing $50 \mathrm{mM}$ Tris (pH 7.4), $150 \mathrm{mM} \mathrm{NaCl}, 1 \%$ Triton X-100, 1 mM EDTA, 1 mM ethylene glycol tetraacetic acid, $1 \mathrm{mM}$ phenylmethylsulfonyl fluoride, $10 \mu \mathrm{g} / \mathrm{ml}$ aprotinin, $10 \mu \mathrm{g} / \mathrm{ml}$ leupeptin, $1 \mathrm{mM}$ sodium orthovandate and $1 \mathrm{mM}$ NaF. The cell lysates were centrifuged at 12,000 $\mathrm{x} g$ for $45 \mathrm{~min}$ at $4^{\circ} \mathrm{C}$ to collect the supernatant. A Bradford protein assay was used to determine the protein concentration. The proteins $(40 \mu \mathrm{g})$ were separated using 12\% SDS-PAGE and then transferred onto a polyvinylidene difluoride membrane (EMD Millipore, Billerica, MA, USA). The membranes were blocked using $5 \%$ non-fat milk, followed by overnight incubation with primary antibodies at $4{ }^{\circ} \mathrm{C}$. The primary antibodies used were as follows: Cyclin E (1:1,000; cat. no. sc-377100), cell division cycle 25C (Cdc25c; 1:1,000; cat. no. sc-13138), p21 (1:1,00; cat. no. sc-6246), Bcl-2-associated X protein (Bax; 1:1,000; cat. no. sc-526), apoptosis-inducing factor (AIF; 1:1,000; cat. no. sc-5586), caspase-3 (1:1,000; cat. no. sc-7148), and poly(ADP-ribose) polymerase (PARP; 1:2,000; cat. no. sc-7150) all obtained from Santa Cruz Biotechnology, Inc., and phosphorylated (p)-p53 (1:50; cat. no. PA5-27822), B cell lymphoma-2 (Bcl-2; 1:200; cat. no. PA1-28275), caspase-9 (1:1,000; cat. no. KHZ0102) and caspase-8 (1:1,000; cat. no. MA1-41280) all obtained from Thermo Fisher Scientific, Inc., and endonuclease G (Endo G; 1:1,000; Koma Biotech, Seoul, Korea). Following incubation with primary antibodies, the membranes were washed with Tween and PBS and then incubated again for $1 \mathrm{~h}$ at room temperature with horseradish peroxidase-conjugated secondary antibody (1:3,000; Bio-Rad Laboratories, Inc., Hercules, CA, USA; cat. no. 170-6515). Electrochemiluminesence reagent (GE Healthcare Life Sciences, Amersham, UK) was used to analyze the bound antibody complexes and $\beta$-actin $(1: 1,000$; Santa Cruz Biotechnology, Inc.; cat. no. sc-47778) served as an internal control. A gel imaging analysis system (Kodak 
ID; Kodak, Rochester, NY, USA) was used to analyze the bands.

Confocal laser scanning microscopy for the assessment of protein translocation. The BHP-treated T24 cells $\left(2.5 \times 10^{5}\right)$ were placed into glass bottom culture dishes (MatTek Corporation, Ashland, MA, USA) and cultured for $24 \mathrm{~h}$. The culture medium was replaced with normal HEPES buffer containing $135 \mathrm{mM}$ $\mathrm{NaCl}, 5.4 \mathrm{mM} \mathrm{KCl}, 1 \mathrm{mM} \mathrm{MgCl}{ }_{2}, 1.8 \mathrm{mM} \mathrm{CaCl}_{2}, 5 \mathrm{mM}$ HEPES and $10 \mathrm{mM}$ glucose (pH 7.3). Following the elimination of $\mathrm{CaCl}_{2}$ or $\mathrm{MgCl}_{2}$, the fluorescence was monitored using a confocal laser scanning fluorescent microscope (LSM 410 invert; Carl Zeiss AG, Jena, Germany) at an argon excitation of $488 \mathrm{~nm}$ using a 515-nm-long pass barrier filter. All experiments were performed in triplicate at the room temperature.

Statistical analysis. All experiments were performed three times and the data obtained was analyzed using SPSS version 12.0 (SPSS, Inc., Chicago, IL, USA). The values are presented as the mean \pm standard deviation. For the evaluation of two groups, Student's $t$-test was used. $\mathrm{P}<0.05$ was considered to indicate a statistically significant difference.

\section{Results}

BHP treatment induces alterations in morphology, decreases viability and arrests cell cycle in T24 cells. The investigation of the T24 cell growth, cell viability and cell cycle arrest revealed that BHP had concentration- and time-dependent effects. BHP exposure for $48 \mathrm{~h}$ induced significant changes in the morphology of T24 bladder carcinoma cells (Fig. 1A). Among the range of BHP concentrations between 2 and $10 \mu \mathrm{M}$ used for treatment of the cells, the inhibition in growth and viability of T24 cells was significant at $8 \mu \mathrm{M}$ following $48 \mathrm{~h}$ treatment. At the $8 \mu \mathrm{M}$ concentration of BHP, the cell viability was reduced to $26 \%$, compared with that of the control cells (Fig. 1B). Analysis of the cell cycle revealed a marked increase in the proportion of cells in the G0/G1 phase following treatment with BHP for $48 \mathrm{~h}$, compared with the untreated cells (Fig. 1C and D).

BHP treatment induces DNA damage and apoptosis in T24 cells. The results from the DAPI and Annexin V staining revealed that BHP treatment for $48 \mathrm{~h}$ induced the condensation of DNA in T24 cells. A reduction in the cell population and the induction of apoptosis in T24 cells were also observed following $48 \mathrm{~h}$ of treatment (Fig. 2A and B).

BHP treatment enhances the production of $\mathrm{ROS}$ and $\mathrm{Ca}^{2+}$, and reduces the MMP in T24 cells. The effects of BHP on the generation of ROS and $\mathrm{Ca}^{2+}$, and on the MMP of the cells were investigated using 2, 5, 8 and $10 \mu \mathrm{M}$ concentrations of $\mathrm{BHP}$ to treat the T24 cells. The results showed that exposure of the cells to 2 and $5 \mu \mathrm{M}$ BHP induced a marked enhancement in ROS and $\mathrm{Ca}^{2+}$ generation (Fig. 3A and B), however, ROS remained constant at 8 and $10 \mu \mathrm{M}$. However, the MMP in the T24 cells was reduced significantly following $48 \mathrm{~h}$ of BHP exposure (Fig. 3C).

BHP treatment induces the translocation of apoptotic protein in T24 cells. The results from the confocal laser microscopy revealed that the exposure of T24 cells to BHP for $24 \mathrm{~h}$ induced translocation of Endo $\mathrm{G}$ and AIF from the cell mitochondria into the nucleus (Fig. 4A and B). For confirmation of these findings, double-immunofluorescence labeling was performed, and the results obtained were in agreement with those of the confocal laser microscopy.

BHP treatment induces the expression of apoptotic proteins in T24 cells. The results from the western blot analysis showed that treatment of the T24 bladder cancer cells with BHP enhanced the expression levels of p21 and p-p53, however, the expression levels of cyclin $\mathrm{E}$ and $\mathrm{Cdc} 25 \mathrm{c}$ were reduced following BHP treatment (Fig. 5A). The exposure of T24 bladder cancer cells to BHP promoted the expression of proteins, including Bax, cleavage-caspases, AIF, Endo G and PARP, but reduced the expression of Bcl-2 in the cytoplasm (Fig. 5A and B).

\section{Discussion}

2-pyrones, the cyclic, unsaturated compounds with a six-membered ring structure, exhibit potent anticancer and anti-HIV activities (16-18). In human leukemic cells, exposure to tricyclic 2-pyrones induces the inhibition of DNA synthesis and the rate of cell proliferation (19). The present study was performed with the aim of demonstrating the effect of BHP on cell cycle and apoptosis in T24 bladder cancer cells.

The results obtained in the present study revealed that BHP treatment caused inhibition of cell growth in the T24 bladder cancer cells. Exposure of the bladder carcinoma cells to BHP resulted in arrest of the cell cycle in the G0/G1 phase of the cycle. This cell cycle arrest in the G0/G1 phase may have been due to the enhanced expression levels of p53 and p21, and the reduced expression levels of Cdc25c and cyclin E. Progression of the cell cycle is maintained by various factors, including cyclins, which are vital for the activation of protein kinases and caspases (20). The results of the present study demonstrated that exposure of the bladder cancer cells to BHP treatment enhanced the activation of caspases. It also resulted in the secretion of AIF and Endo G from the mitochondria, and their translocation into the nucleus. These alterations induced a decrease in the MMP of the cells, suggesting that BHP treatment caused apoptosis in the bladder carcinoma cells through the mitochondrial pathway.

In order for alterations in membrane permeability of mitochondria and for caspase activation, factors belonging to the Bcl-2 family are involved (21-23). The present study demonstrated that BHP treatment enhanced the protein expression level of pro-apoptotic Bax and inhibited the protein expression of anti-apoptotic Bcl-2. The enhanced generation of ROS in response to anti-oxidant agents results in oxidative stress, cell cycle arrest and the apoptosis of cells $(24,25)$. The results from the present study revealed that BHP treatment enhanced the generation of ROS and $\mathrm{Ca}^{2+}$, and caused arrest of cell cycle in the G0/G1 phase in the T24 bladder cancer cells.

There are previous reports that the activation of JNK induces the expression of p21, Bcl-2-associated death promoter, Bcl-2 homologous antagonist/killer and tumor necrosis factor- $\alpha$ (26-29). However, the results from the present study revealed that BHP promoted the expression of these factors, suggesting the involvement of JNK in the 
A
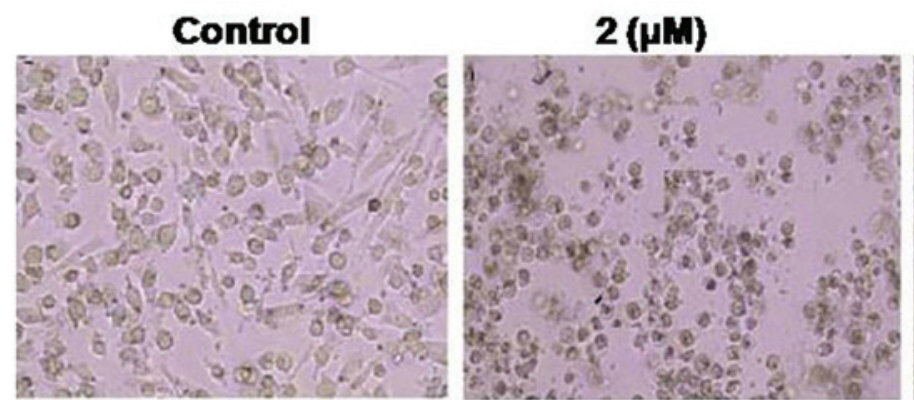

$5(\mu \mathrm{M})$

$8(\mu \mathrm{M})$

$10(\mu \mathrm{M})$
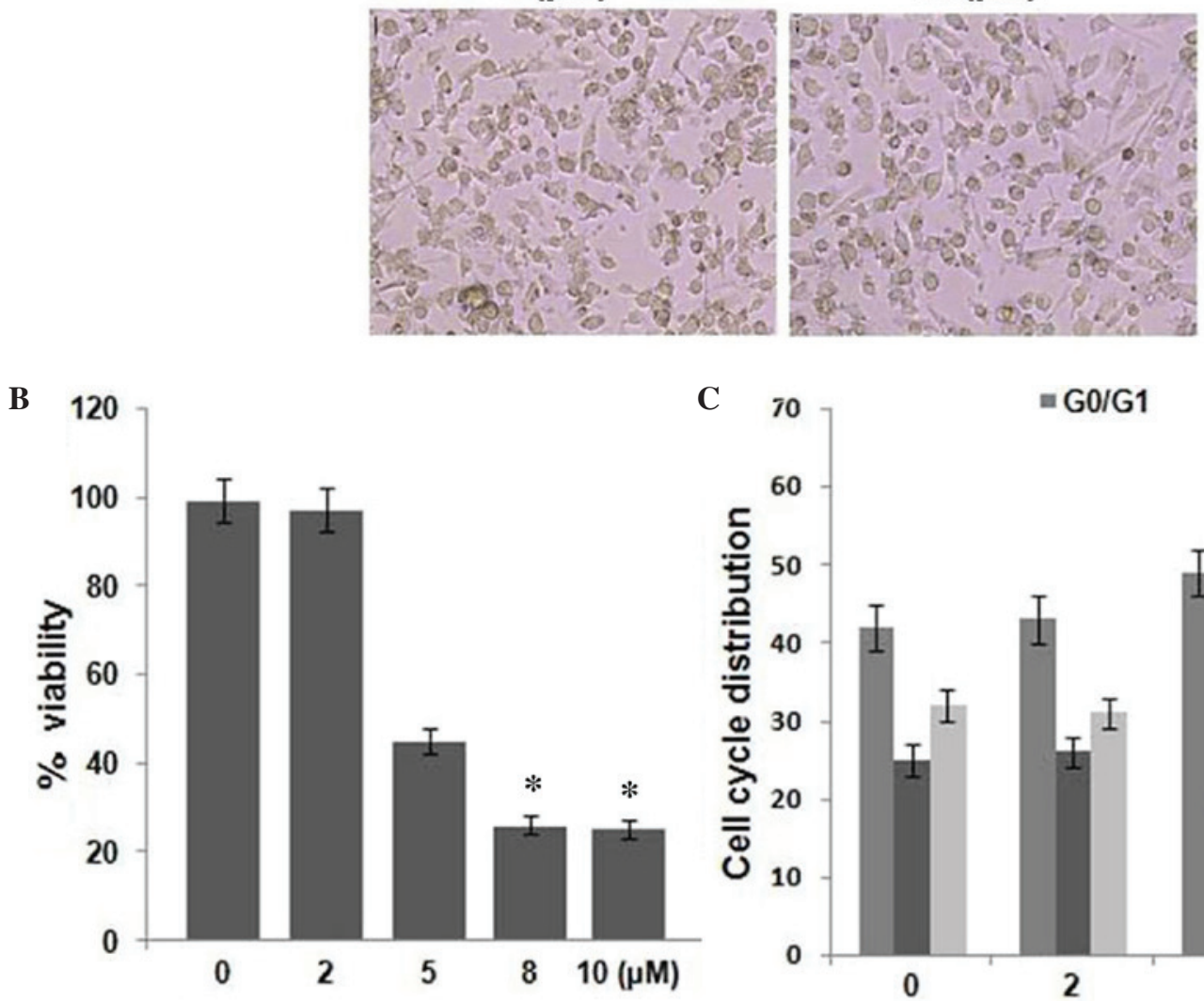

FL2-A
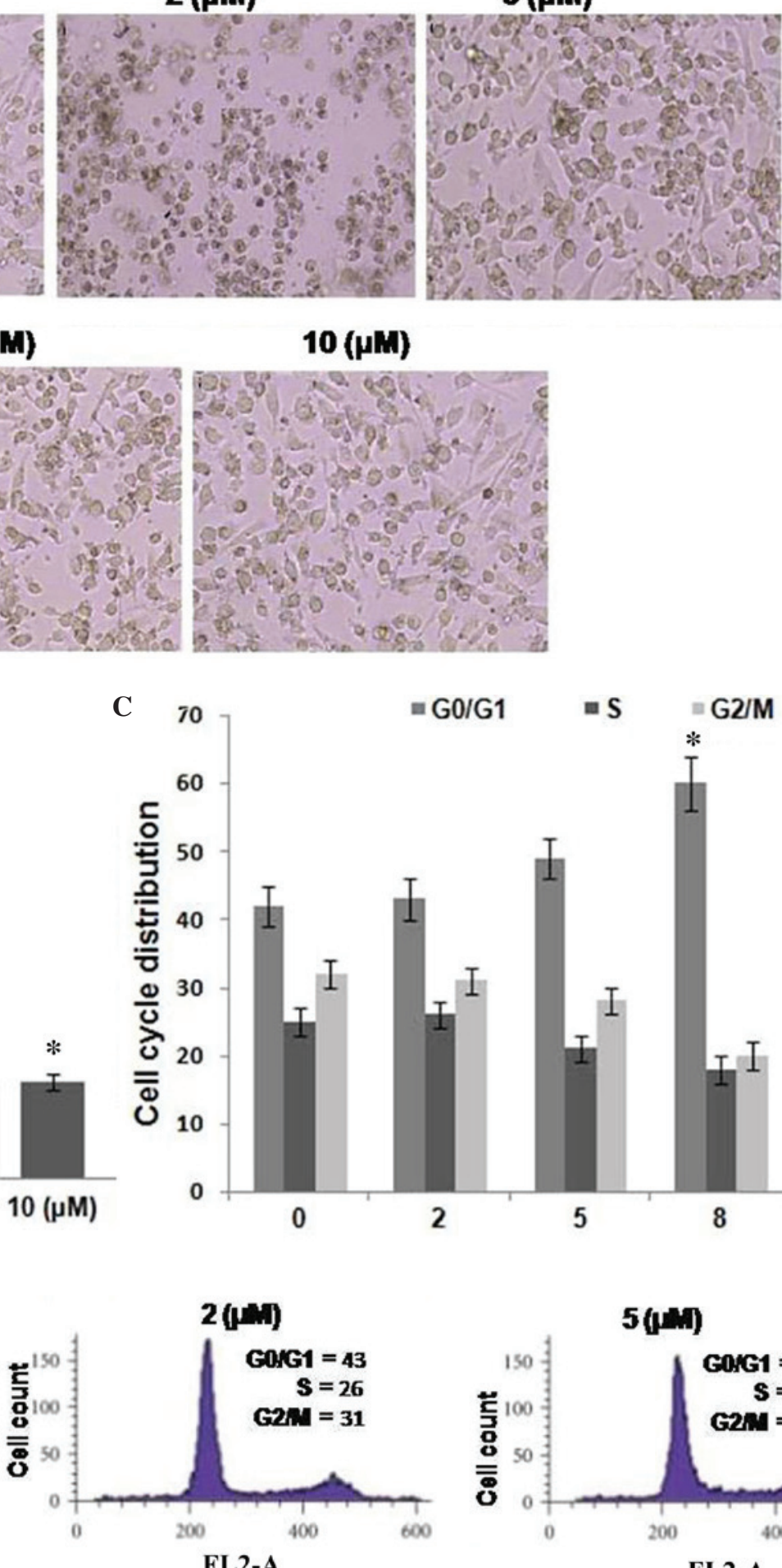

D
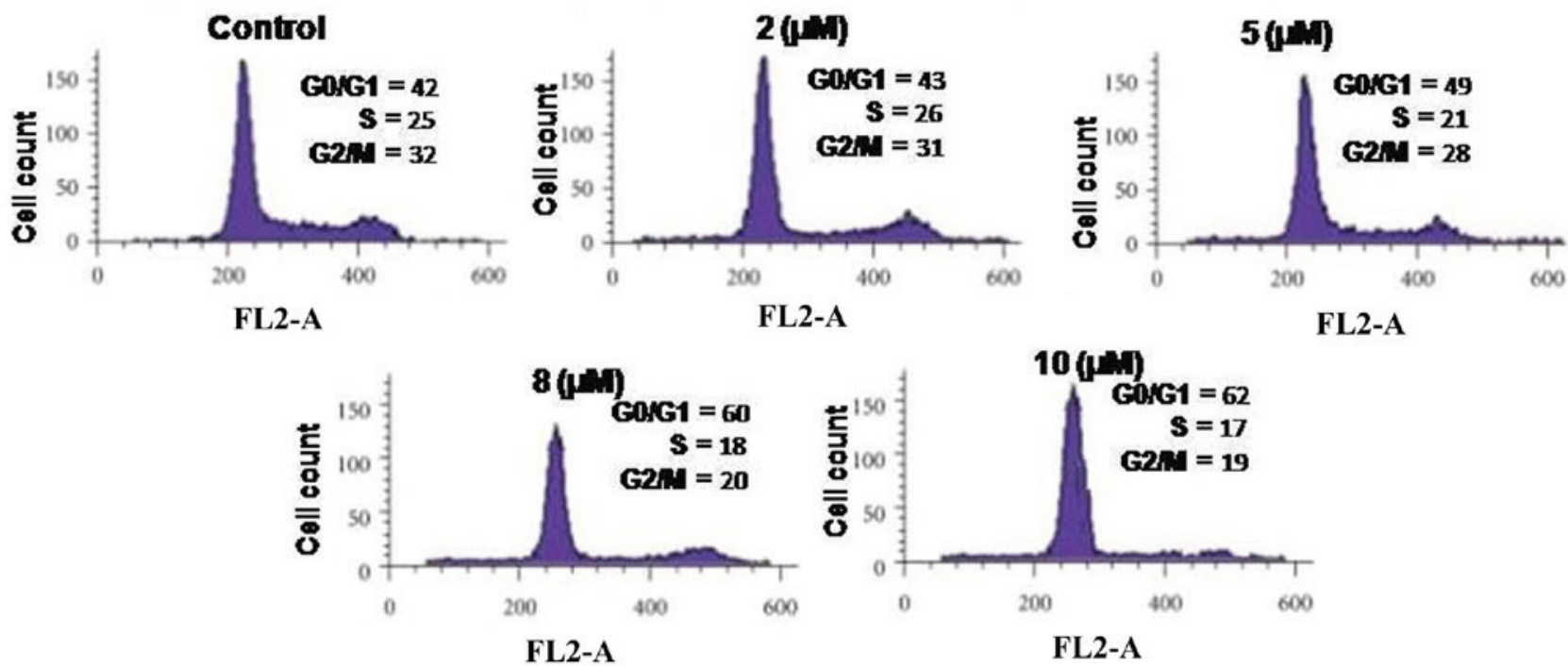

Figure 1. Effect of BHP on T24 bladder carcinoma cell morphology and viability. The cells were incubated with $0,2,5,8$ and $10 \mu \mathrm{M}$ of BHP for $48 \mathrm{~h}$, followed by observations of (A) morphological alterations using phase-contrast microscopy (magnification, x200) and (B) cell viability using an MTT assay. (C and D) BHP induced cell cycle arrest in the T24 cells, determined using flow cytometry. Values are presented as the mean \pm standard deviation. ${ }^{*} \mathrm{P}<0.05$ vs. the control group. BHP, 5-bromo-3-(3-hydroxyprop-1-ynyl)-2H-pyran-2-one. 


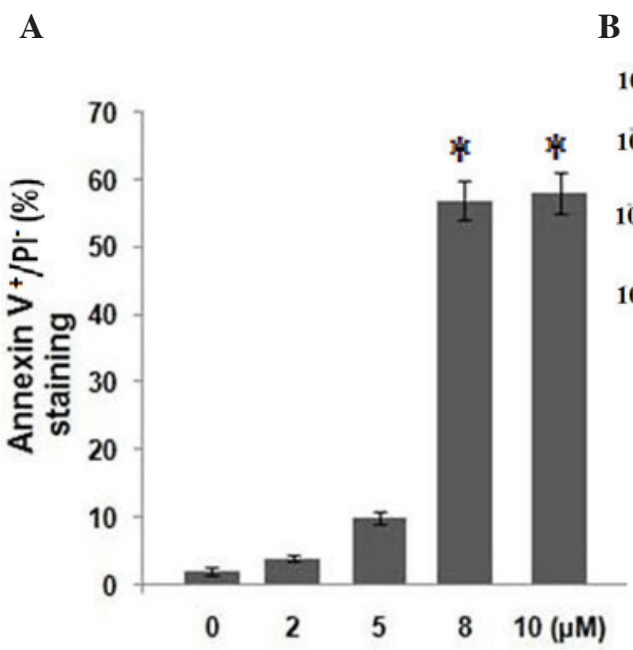

B
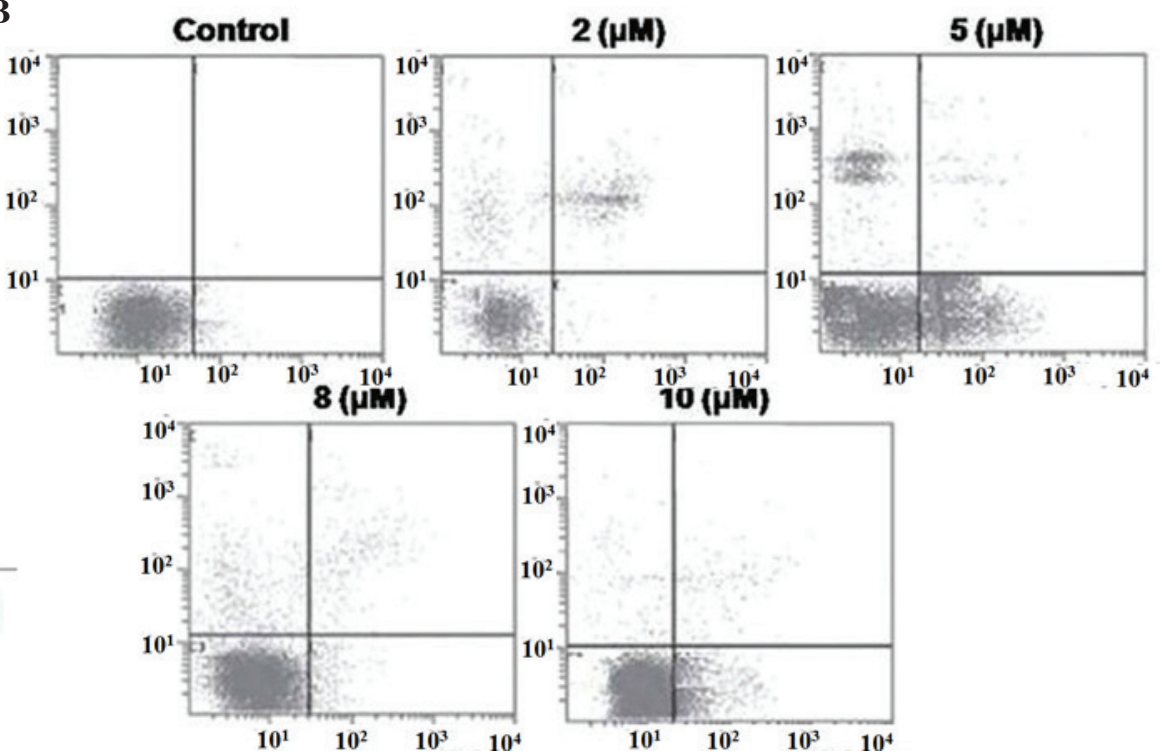

Figure 2. Treatment of T24 cells with BHP induces DNA damage and apoptosis. The cells were exposed to $0,2,5$ and $10 \mu \mathrm{M}$ of BHP for $24 \mathrm{~h}$ and examined for (A) DNA damage using 4,6-diamidino-2-phenylindole dihydrochloride staining, and for (B) apoptosis using Annexin V staining and flow cytometry. Values are presented as the mean \pm standard deviation. ${ }^{*} \mathrm{P}<0.05$ vs. the control group. BHP, 5-bromo-3-(3-hydroxyprop-1-ynyl)- $2 H$-pyran-2-one.

$\mathbf{A}$

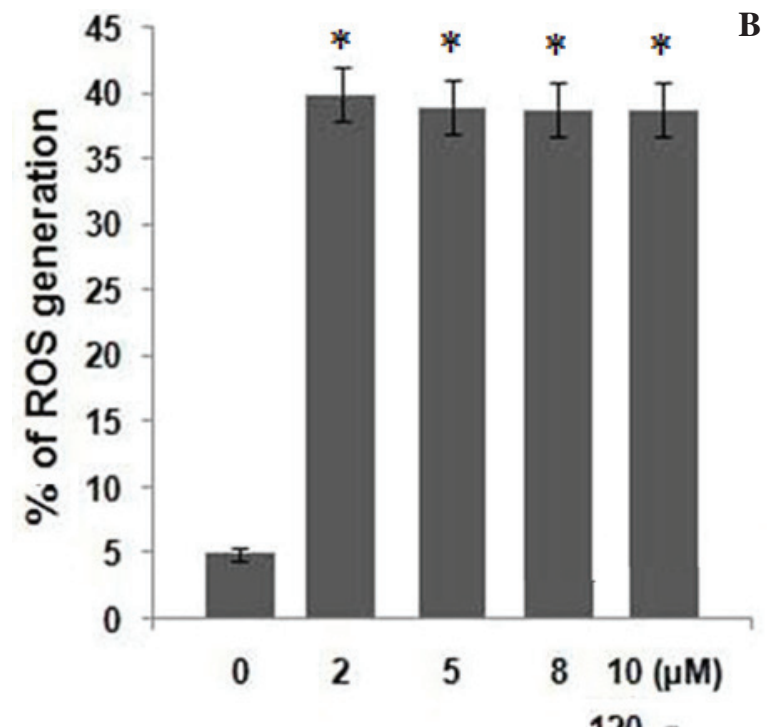

B

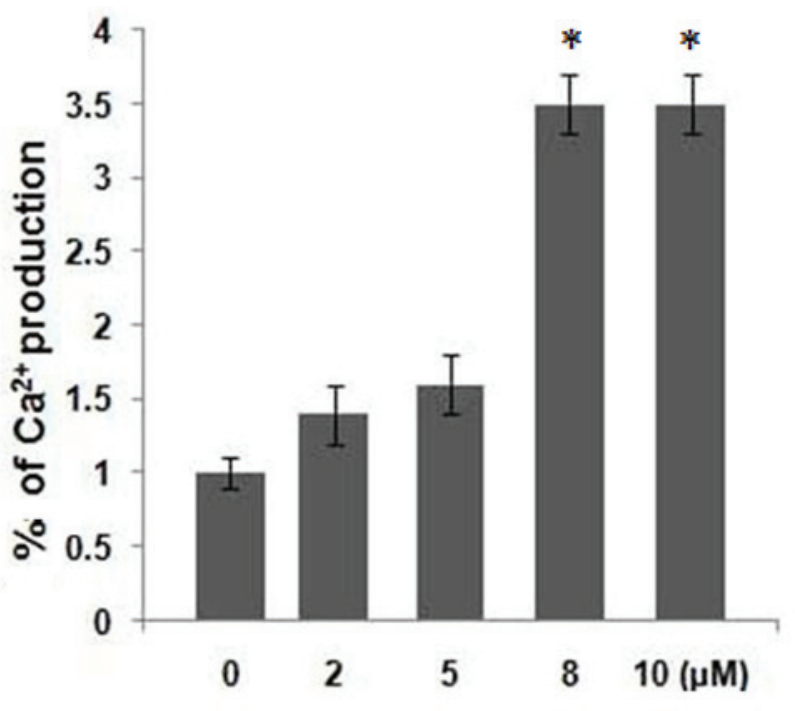

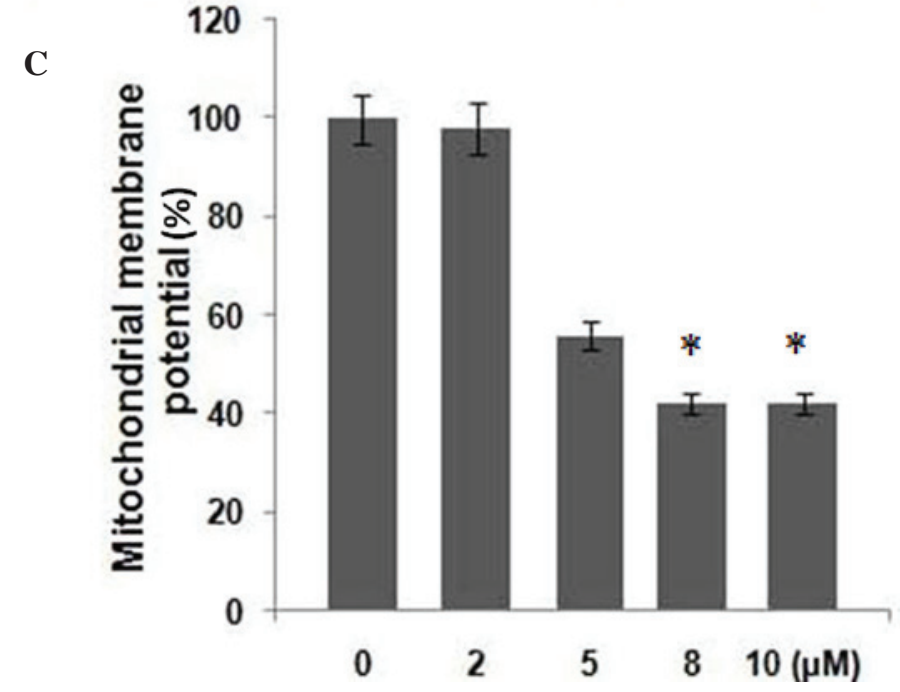

Figure 3. BHP treatment induces the generation of ROS and production of $\mathrm{Ca}^{2+}$, and decreases the membrane potential of mitochondria in T24 cells. T24 cells were exposed to BHP and the (A) generation of ROS, (B) $\mathrm{Ca}^{2+}$ and (C) alterations in membrane potential were determined. Values are presented as the mean \pm standard deviation. ${ }^{*} \mathrm{P}<0.05$ vs. the control group. BHP, 5-bromo-3-(3-hydroxyprop-1-ynyl)-2H-pyran-2-one; ROS, reactive oxygen species. 


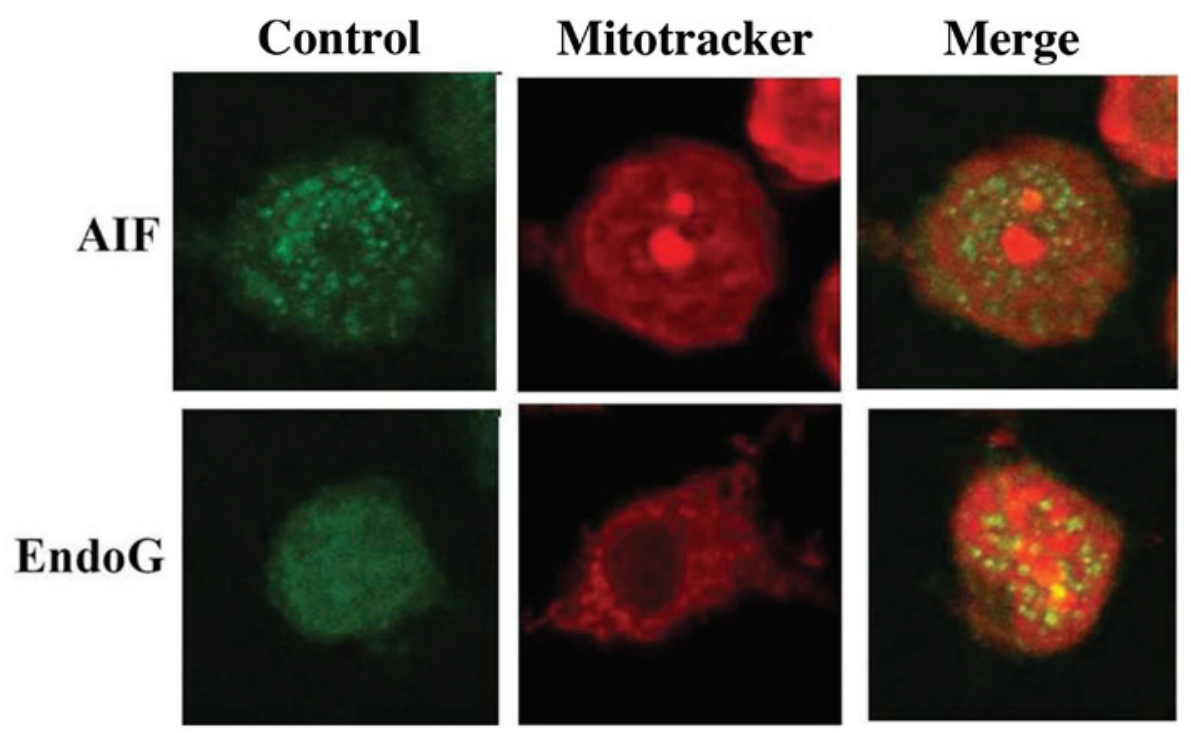

Figure 4. BHP treatment alters the expression levels of Endo G and AIF in T24 cells. Following incubation with BHP, the T24 cells were stained with primary Endo G and AIF antibodies and then visualized using a confocal laser microscopic system. Magnification, x200. BHP, 5-bromo-3-(3-hydroxyprop-1-ynyl)-2H-pyran-2-one; AIF, apoptosis-inducing factor; Endo G, endonuclease G.

A

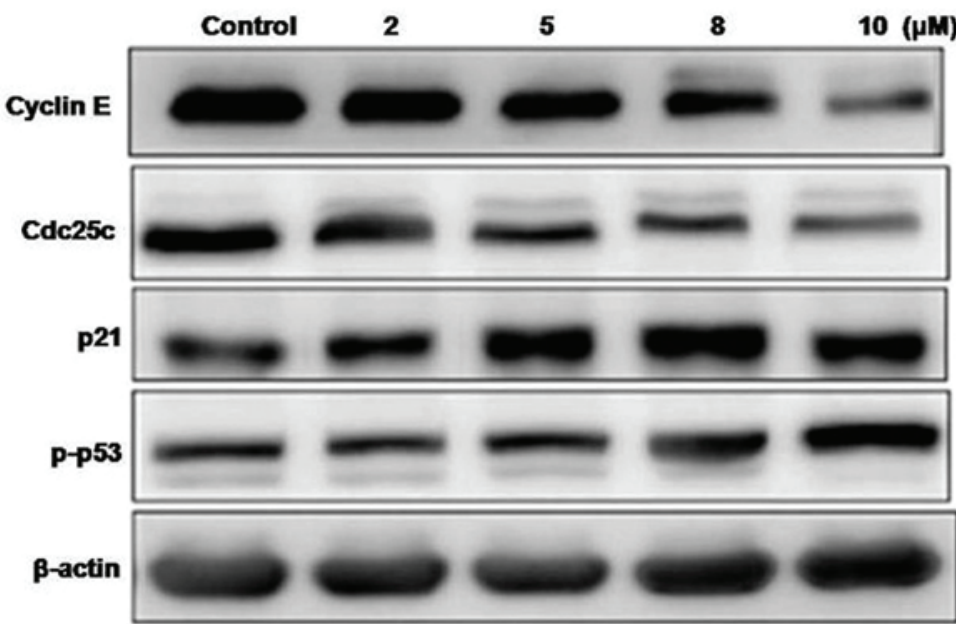

B

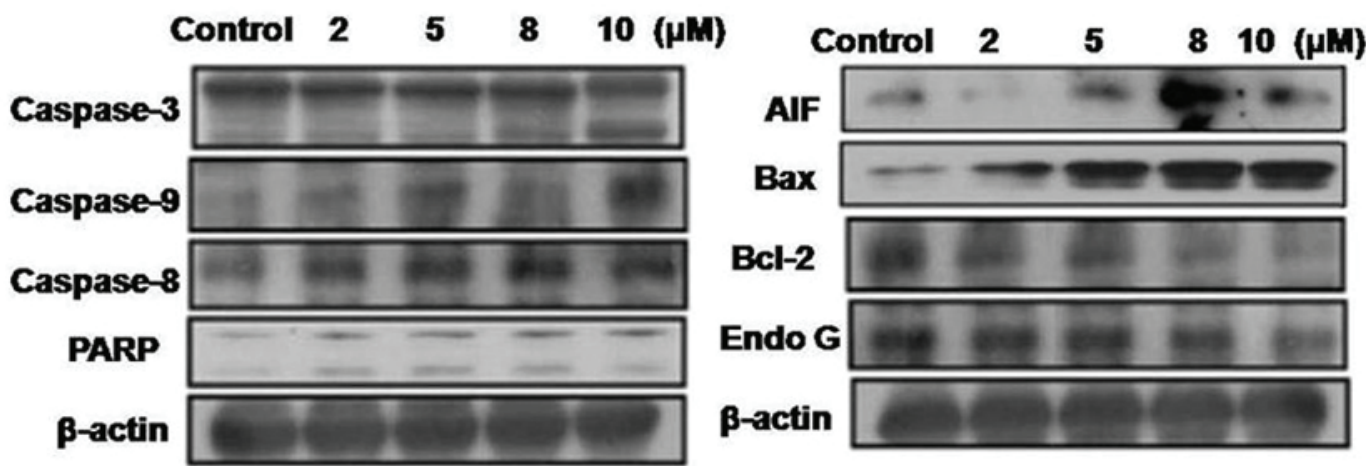

Figure 5. BHP treatment alters expression levels of cell cycle proteins and apoptosis-inducing proteins in T24 cells. The cells were exposed to various concentrations of BHP and subjected to western blot analysis for (A) cell cycle and (B) apoptotic proteins. Cdc25c, cell division cycle 25C; p-p53, phosphorylated p53; PARP, poly(ADP-ribose) polymerase; AIF, apoptosis-inducing factor; Bcl-2, B cell lymphoma-2; Bax, Bcl-2-associated X protein; Endo G, endonuclease G.

BHP-induced cell cycle arrest and apoptosis in bladder carcinoma cells.

In conclusion, BHP treatment enhanced the activation of caspases and increased the production of ROS. It also resulted in DNA damage, reduced MMP, and increased secretion of endonuclease $\mathrm{G}$ and apoptosis-inducing factors from the mitochondria. This decreased the cell viability, induced arrest of the cell cycle in the G0/G1 phase and induced apoptosis in the bladder cancer cells. Thus, it is hypothesized that BHP may be a promising molecule in the chemoprevention or chemotherapy 
in human bladder cancer cells, and future research to investigate its effects are required.

\section{Acknowledgements}

The authors would like to thank the Head of the Department of Urological Surgery at The First Affiliated Hospital, Henan University (Luoyang, China) for his generous support.

\section{References}

1. Kaufman DS, Shipley WU and Feldman AS: Bladder cancer. Lancet 374: 239-249, 2009.

2. Jemal A, Bray F, Center MM, Ferlay J, Ward E and Forman D: Global cancer statistics. CA Cancer J Clin 61: 69-90, 2011.

3. Kwak C, Ku JH, Park JY, Lee E, Lee SE and Lee C: Initial tumor stage and grade as a predictive factor for recurrence in patients with stage T1 grade 3 bladder cancer. J Urol 171: 149-152, 2004.

4. Sternberg CN, Yagoda A, Scher HI, Watson RC, Geller N, Herr HW, Morse MJ, Sogani PC, Vaughan ED, BanderN, et al: Methotrexate, vinblastine, doxorubicin, and cisplatin for advanced transitional cell carcinoma of the urothelium. Efficacy and patterns of response and relapse. Cancer 64: 2448-2458, 1989.

5. Orren DK, Petersen LN and Bohr VA: Persistent DNA damage inhibits S-phase and G2 progression and results in apoptosis. Mol Biol Cell 8: 1129-1142, 1997.

6. Fujimoto K, Hosotani R, Doi R, Wada M, Lee JU, Koshiba T, Miyamoto Y, Tsuji S, Nakajima S and Imamura M: Induction of cell-cycle arrest and apoptosis by a novel retinobenzoic-acid derivative, TAC-101, in human pancreatic-cancer cells. Int J Cancer 81: 637-644, 1999.

7. Gamet-Payrastre L, Li P, Lumeau S, Cassar G, Dupont MA, Chevolleau S, Gasc N, Tulliez J and Tercé F: Sulforaphane, a naturally occurring isothiocyanate, induces cell cycle arrest and apoptosis in HT29 human colon cancer cells. Cancer Res 60: 1426-1433, 2000.

8. Nakagawa T, Zhu H, Morishima N, Li E, Xu J, Yankner BA and Yuan J: Caspase-12 mediates endoplasmic-reticulum-specific apoptosis and cytotoxicity by amyloid-beta. Nature 403: 98-103, 2000.

9. Srinivasula SM, Hegde R, Saleh A, Datta P, Shiozaki E, Chai J, Lee RA, Robbins PD, Fernandes-Alnemri T, Shi Y and Alnemri ES: A conserved XIAP-interaction motif in caspase-9 and Smac/DIABLO regulates caspase activity and apoptosis Nature 409: 112-116, 2001

10. Degterev A, Boyce M and Yuan J: A decade of caspases. Oncogene 22: 8543-8567, 2003.

11. Ziegler DS and Kung AL: Therapeutic targeting of apoptosis pathways in cancer. Curr Opin Oncol 20: 97-103, 2008.

12. Jensen PR and Fenical W: Strategies for the discovery of secondary metabolites from marine bacteria: Ecological perspectives. Annu Rev Microbiol 48: 559-584, 1994.
13. Faulkner DJ: Marine natural products. Nat Prod Rep 18: 1-49, 2001

14. McGlacken GP and Fairlamb IJ: 2-Pyrone natural products and mimetics: Isolation, characterisation and biological activity. Nat Prod Rep 22: 369-385, 2005.

15. Dickinson JM: Microbial pyran-2-ones and dihydropyran-2-ones. Nat Prod Rep 10: 71-98, 1993.

16. Thaisrivongs S, Romero DL, Tommasi RA, Janakiraman MN, Strohbach JW, Turner SR, Biles C, Morge RR, Johnson PD, Aristoff PA, et al: Structure-based design of HIV protease inhibitors: 5,6-dihydro-4-hydroxy-2-pyrones as effective, nonpeptidic inhibitors. J Med Chem 39: 4630-4642, 1996.

17. Poppe SM, Slade DE, Chong KT, Hinshaw RR, Pagano PJ, Markowitz M, Ho DD, Mo H, Gorman RR III, Dueweke TJ, et al: Antiviral activity of the dihydropyrone PNU-140690, a new nonpeptidic human immunodeficiency virus protease inhibitor. Antimicrob Agents Chemother 41: 1058-1063, 1997.

18. Turner SR, Strohbach JW, Tommasi RA, Aristoff PA, Johnson PD, Skulnick HI, Dolak LA, Seest EP, Tomich PK, Bohanon MJ, et al: Tipranavir (PNU-140690): A potent, orally bioavailable nonpeptidic HIV protease inhibitor of the 5,6-dihydro-4-hydroxy-2-pyrone sulfonamide class. J Med Chem 41: 3467-3476, 1998 .

19. Trachootham D, Lu W, Ogasawara MA, Nilsa RD and Huang P: Redox regulation of cell survival. Antioxid Redox Signal 10: 1343-1374, 2008

20. Hartwell LH and Weinert TA: Checkpoints: Controls that ensure the order of cell cycle events. Science 246: 629-634, 1989.

21. Adams JM and Cory S: The Bcl-2 protein family: Arbiters of cell survival. Science 281: 1322-1326, 1998.

22. Antonsson B and Martinou JC: The Bcl-2 protein family. Exp Cell Res 256: 50-57, 2000.

23. Salvesen GS and Dixit VM: Caspases: Intracellular signaling by proteolysis. Cell 91: 443-446, 1997.

24. Rauh R, Kahl S, Boechzelt H, Bauer R, Kaina B and Efferth T: Molecular biology of cantharidin in cancer cells. Chin Med 2: 8, 2007.

25. Ozben T: Oxidative stress and apoptosis: Impact on cancer therapy. J Pharm Sci 96: 2181-2196, 2007.

26. Xiao L, Eto $\mathrm{M}$ and Kazanietz MG: ROCK mediates phorbol ester-induced apoptosis in prostate cancer cells via p21Cip1 upregulation and JNK. J Biol Chem 284: 29365-29375, 2009.

27. Lin KL, Su JC, Chien CM, Tseng CH, Chen YL, Chang LS and Lin SR: Naphtho [1,2-b]furan-4,5-dione induces apoptosis and S-phase arrest of MDA-MB-231 cells through JNK and ERK signaling activation. Toxicol In Vitro 24: 61-70, 2010.

28. Choi YJ, Kim SY, Oh JM and Juhnn YS: Stimulatory heterotrimeric $\mathrm{G}$ protein augments gamma ray-induced apoptosis by up-regulation of Bak expression via CREB and AP-1 in HL299 human lung cancer cells. Exp Mol Med 41: 592-600, 2009.

29. An L, Dong GQ, Gao Q, Zhang Y, Hu LW, Li JH and Liu Y: Effects of UVA on TNF-alpha, IL-1beta, and IL-10 expression levels in human keratinocytes and intervention studies with an antioxidant and a JNK inhibitor. Photodermatol Photoimmunol Photomed 26: 28-35, 2010. 